\title{
Geologic evidence for coseismic uplift at AD 400 in coastal lowland deposits on the Shimizu Plain, central Japan
}

\author{
Akihisa Kitamura ${ }^{1,2^{*}}$ D, Tomoya Ina ${ }^{3}$, Daisuke Suzuki ${ }^{3}$, Keito Tsutahara ${ }^{3}$, Daisuke Sugawara ${ }^{4}$, Kazuyoshi Yamada ${ }^{4}$ and \\ Akira Aoshima $^{3}$
}

\begin{abstract}
Megathrust earthquakes of magnitude $\sim 8$ and ensuing large tsunamis occur along the Nankai and Suruga troughs, central Japan, with a recurrence interval of 90-270 years since an AD 684 Hakuho earthquake. Historical records show that the AD 1854 Ansei-Tokai earthquake caused coseismic uplift of $\sim 1 \mathrm{~m}$ in coastal areas west of Suruga Bay, including the Shimizu Plain, east Shizuoka Prefecture. The 1361 Shohei Tokai earthquake was accompanied by coseismic uplift, but no evidence has been found to indicate uplift before the earthquake. This study examined sediment cores recovered from the coastal beach ridge in the Shimizu Plain using sedimentological and paleontological analyses and radiocarbon dating. We infer from the results that a relative sea-level fall of $1.6 \mathrm{~m}$ took place at AD 398-428. This coincides with archeological evidence suggesting the occurrence of a large earthquake in west Shizuoka Prefecture in AD 400. This combination of evidence indicates that the drop in sea level was caused by coseismic uplift associated with a megathrust rupture along the Suruga Trough, with a recurrence interval of $\sim 500-1000$ years. The results also indicate that a megathrust rupture occurred in the region from the Eastern Nankai Trough to the Suruga Trough at ca. AD 400.
\end{abstract}

Keywords: Sediment core, Coseismic uplift, Facies analysis, Late Holocene, Nankai and Suruga troughs, Paleoseismology, Shimizu Plain

\section{Introduction}

The 2011 off the Pacific coast of Tohoku earthquake was the largest earthquake recorded (Mw 9.0) in Japan, and it generated a mega-tsunami that severely damaged the coastal areas (CDMC, 2011). Following this event, the Japanese Government re-assessed the earthquakes and tsunamis expected in the future in the Suruga and Nankai troughs, close to central and western Japan (Fig. 1). Many studies have examined the earthquakes and tsunami events along subduction zones (e.g., Atwater 1987; Minoura et al. 2001; Nanayama et al. 2003; Monecke et al. 2008; Shishikura et al. 2010; Ishimura and Miyauchi 2015; Kitamura 2016; Inoue et al. 2017; Ando et al. 2018;

\footnotetext{
* Correspondence: kitamura.akihisa@shizuoka.ac.jp

${ }^{1}$ Faculty of Science, Shizuoka University, 836 Ohya, Suruga-ku, Shizuoka 422-8529, Japan

${ }^{2}$ Center for Integrated Research and Education of Natural hazards, Shizuoka University, 836 Ohya, Suruga-ku, Shizuoka 422-8529, Japan

Full list of author information is available at the end of the article
}

Kitamura et al., 2018a, b; Goto et al. 2018). The Philippine Sea Plate is subducting beneath the Eurasian Plate at these troughs, and megathrust earthquakes of magnitude $\sim 8$ and ensuing large tsunamis have occurred since an $\mathrm{AD}$ 684 Hakuho earthquake, with a recurrence interval of 90-270 years (Ando 1975b; Ishibashi 2004).

Historical documents show that the Suruga and Nankai troughs are divided into six segments based on patterns of seismicity, labeled A-E and Z (Ando 1975b; Ishibashi 1976; Furumura et al. 2011). The 1854 AnseiTokai, 1854 Ansei-Nankai, 1944 Tōnankai Earthquake and 1946 Nankai Earthquake were caused by ruptures of segments $\mathrm{C}-\mathrm{E}, \mathrm{A}-\mathrm{B}, \mathrm{C}-\mathrm{D}$ and $\mathrm{A}-\mathrm{B}$, respectively (Ishibashi 1976). Segment E (Suruga Trough) has not ruptured since the 1854 Ansei-Tokai earthquake, and this section shows remarkable interseismic crustal movement. In this context, Ishibashi (1976) predicted that a M-8 earthquake (Tokai earthquake) will occur sooner or later upon this segment. A geodetic precursor 


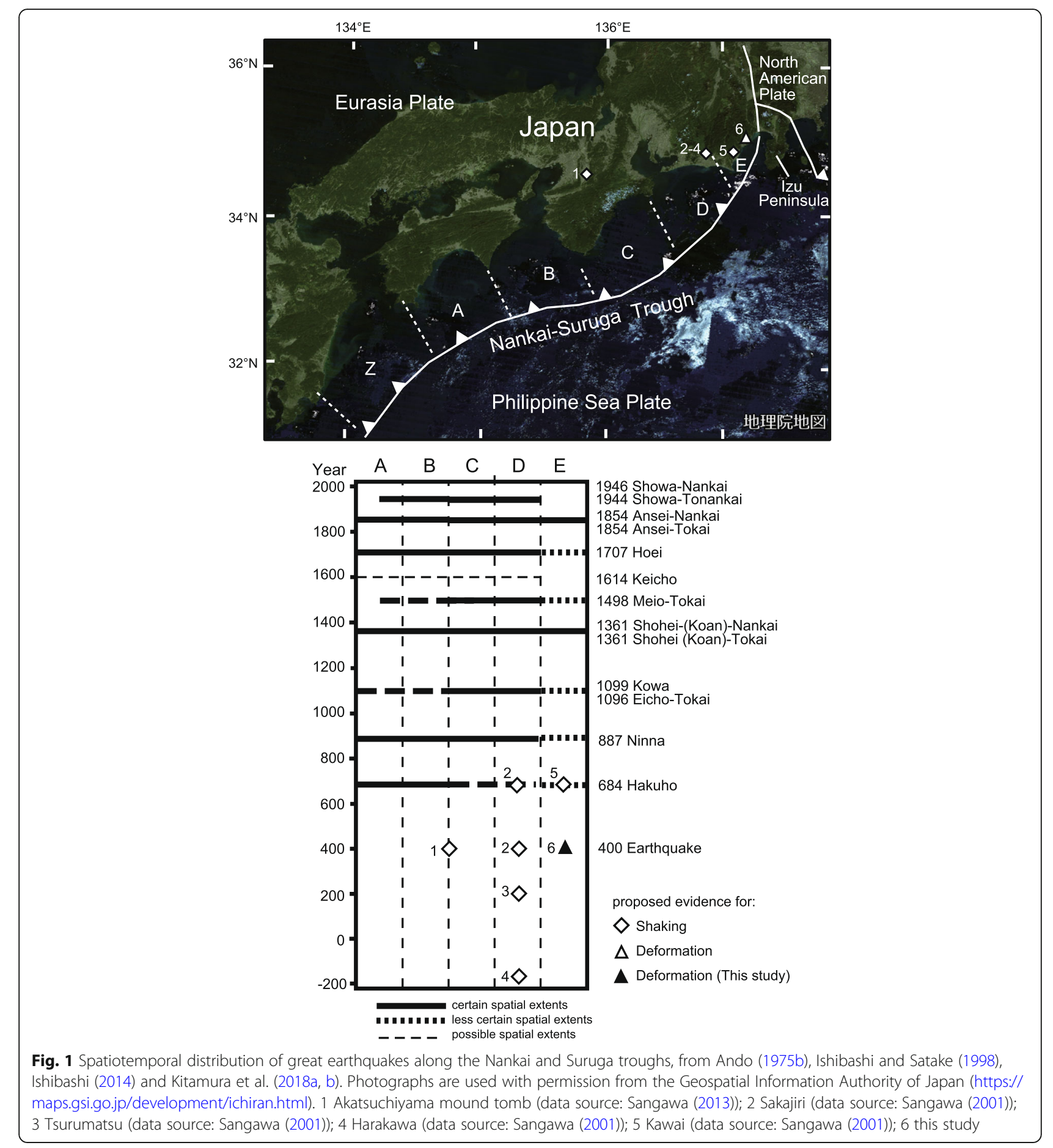

was reported for the 1944 Tōnankai Earthquake (Fig. 1). The data, taken far from the epicentral region, were interpreted as suggesting uplift of a few centimeters due to pre-slip that occurred one or two days before the main shock (Ando 1975a; Sato 1977; Mogi 1984/1985). Consequently, the Japanese government enacted the Large-Scale Earthquake Countermeasures Act (1978) for preparedness and short-term prediction of the Tokai Earthquake, although the earthquake has yet to occur.

During the past 40 years, many studies have investigated the occurrence of the Tokai Earthquake and the feasibility of short-term predictions of this event. For example, both historical and geological records indicate the 1854 Ansei-Tokai earthquake resulted in $1.5-1.8 \mathrm{~m}$ 
of coseismic uplift to the west of the Suruga Trough (Ishibashi 1984; Kitamura and Kobayashi 2014) (Fig. 2), although uplift in the western part of Suruga Bay was not detected during the 1707 Hoei and 1498 Meio earthquakes (Hatori 1975, 1977). On the other hand, Kitamura et al. (2018a, b) recently found emerged fossils of boring bivalves at Cape Omaezaki, which faces seismic segments $\mathrm{D}$ and $\mathrm{E}$, indicating at least $2.5 \mathrm{~m}$ of total coseismic uplift resulting from the Tokai earthquake and the AD 1361 Shohei (Koan)-Nankai earthquake. These findings imply that ruptures of segments $C, D$, and $E$ were simultaneous, and the estimated recurrence interval of $~ 500$ years is consistent with the interval of $450-500$ years reported by Kuroki et al.'s (2004) based on a numerical simulation. However, since the recurrence intervals and sizes of great earthquakes in many subduction zones worldwide are highly variable (e.g., Satake and Atwater 2007; Shimazaki et al. 2011;
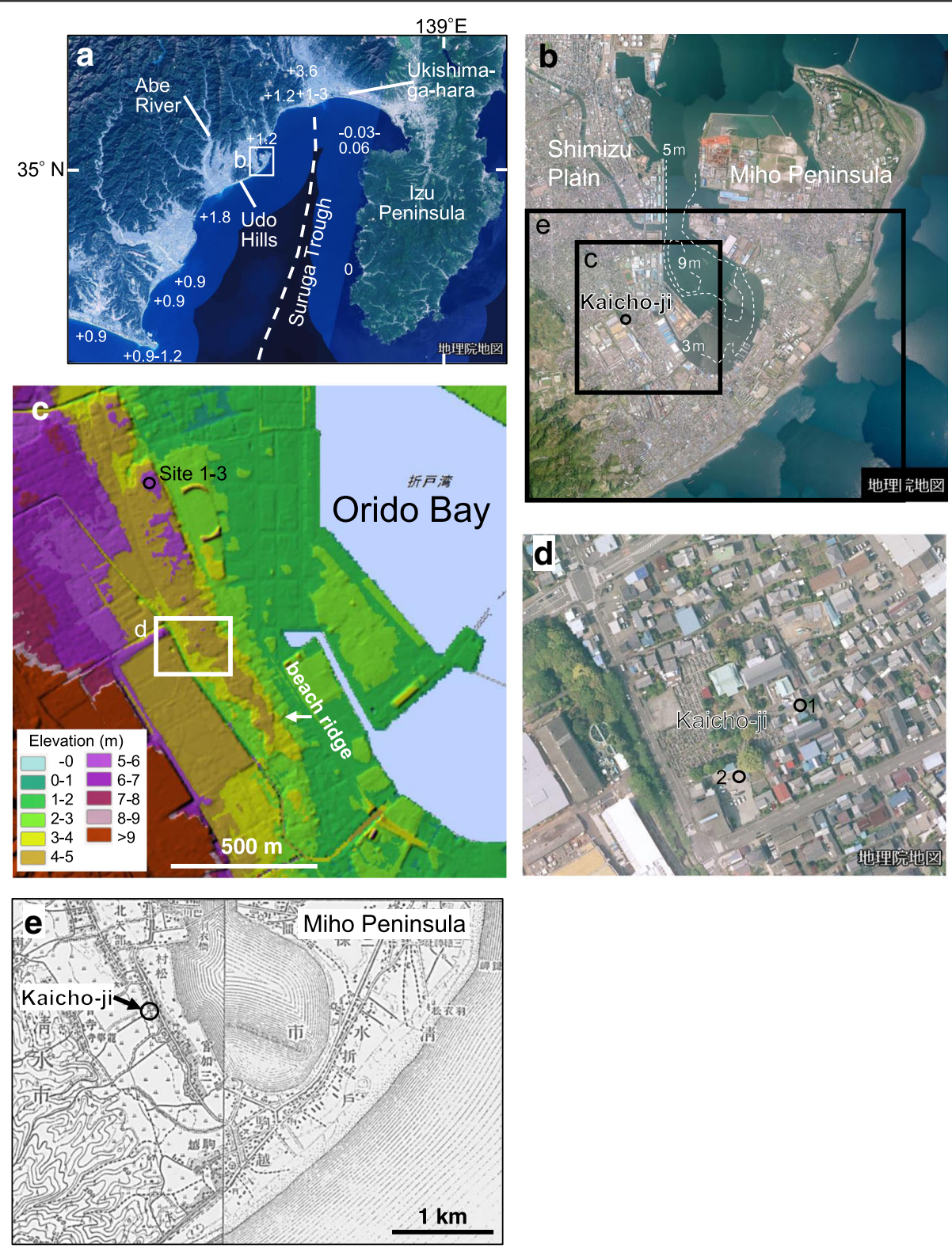

Fig. 2 Locality map of the study area. a Estimated coseismic vertical crustal displacement (m) resulting from the AD 1854 Ansei-Tokai earthquake along the coast of Suruga Bay (after Ishibashi (1984) and Kitamura and Kobayashi (2014)). b Locations of Shimizu Plain, Orido Bay, and Miho Peninsula, showing isobaths are based on Tsuchi (1955). c Location of the study area. The figure is modified from a map issued by the Geospatial Information Authority of Japan (http://maps.gsi.go.jp/). d Aerial photograph of the study area, used with permission from the Geospatial Information Authority of Japan (https://maps.gsi.go.jp/development/ichiran.html). e Topographic map of the Shizuoka and Komagoe districts (1:25,000 scale, compiled in 1932), showing the location of the study area 
Rubin et al. 2017), we must examine the temporal distribution of earthquake prior to the 1361 Shohei Tokai earthquake.

Coseismic uplift events have been identified from geological and geomorphological records such as uplifted marine terraces (e.g., Fujiwara et al. 2010; Komori et al. 2017), emerged marine sessile assemblages (e.g., Shishikura et al. 2008; Iryu et al. 2009; Kitamura et al. 2014, 2015, 2017, Kitamura et al. 2018a, b), and changes in sedimentary facies and microfossil fauna in coastal lowland strata (e.g., Atwater 1987; Nelson et al. 1996a, b; Hayward et al. 2004; Sawai et al. 2004; Shimazaki et al. 2011; Kitamura and Kobayashi, 2014; Mannen et al. 2018). However, geomorphological records can be strongly influenced by human disturbances. Examining the sedimentary features of coastal lowland deposits is a promising approach in reconstructing ancient coseismic uplift events.

This study examines geological evidence for late Holocene megathrust earthquakes based on observations of sedimentary features in cored deposits collected from the area around the Kaicho-ji Temple on the Shimizu Plain, Shizuoka Prefecture, which faces seismic segment E (Fig. 2). The temple was built in AD 1011 on a beach ridge (Fig. 2) with an elevation of about $4 \mathrm{~m}$. This timing provides reliable constraints on the age determination of the emergence of the study area. We identified an abrupt change in sedimentary facies that could have been caused by coseismic uplift during the early fourth century.

\section{Study area}

The Shimizu Plain is a fluvial-coastal lowland adjacent to Orido Bay, which is protected from the open ocean by Miho Peninsula (Fig. 2), a sand and gravel spit with an elevation of up to $10 \mathrm{~m}$ that formed at 5000 years BP (Matsubara, 1989). The Kaicho Temple is located on the beach ridge in the coastal area of the innermost part of Orido Bay. The Miho Peninsula is composed of sediment carried by the Abe River and derived from the Udo Hills to the west of the peninsula (Matsubara, 1989; Ishihara and Mizuno, 2016). The coastline is under a microtidal regime, with a mean tide range of $1.6 \mathrm{~m}$ at Shimizu Port. Tidal gauge data during 1955-2016 show that the Shimizu area has subsided at a rate of c. 6.3 $\mathrm{mm} /$ year (Coordinating Committee for Earthquake Prediction, 2018). According to Tsuchi (1956), mollusk remains collected at $5 \mathrm{~m}$ water depth provide evidence of euxinic and stagnant conditions throughout most of Orido Bay.

The coseismic uplift of the Shimizu Plain resulting from the 1854 Ansei-Tokai earthquake is documented on historical maps compiled immediately after the earthquake and mentioned in interviews conducted 38 years after the earthquake (Hatori 1976, 1977). Based on these accounts, Hatori (1977) and Ishibashi (1984) estimated coseismic uplifts of $1.5-2.0 \mathrm{~m}$ and $3 \mathrm{~m}$, respectively. Kitamura and Kobayashi (2014) reported geological and paleontological evidence indicating a maximum coseismic uplift of $1.2 \mathrm{~m}$ caused by the 1854 Ansei-Tokai earthquake, on the area of the intertidal flat that emerged during the earthquake, and a total post-earthquake subsidence of $\sim 0.6 \mathrm{~m}$. Although historical documents show that the 1707 Hoei and 1498 Meio earthquakes caused damage on the Shimizu Plain, there were no coseismic uplifts (Hatori 1975, 1977). There are no historical records of earthquakes in the region prior to the 1361 Shohei Tokai earthquake. Nevertheless, archeological sites near segments D and E show sand boils and other liquefaction features that indicate intense shaking during certain time periods, including during the mid seventh to early eighth centuries $A D$, the second and early fourth centuries $\mathrm{AD}$, and in the second century BC (Sangawa 2001, 2013) (Fig. 1). It is possible that these intense shaking events were caused by ruptures of segments D and E.

Historical reports also show that the coastal area of the Shimizu Plain was struck by tsunamis associated with the 1854 Ansei-Tokai and 1707 Hoei earthquakes. The wave heights of the tsunami caused by the 1854 Ansei-Tokai earthquake along the northeast-facing coast of the Miho Peninsula and the coastal area of the northern Shimizu Plain are estimated to have been $6 \mathrm{~m}$ and $3 \mathrm{~m}$, respectively (Hatori 1977). No tsunamis have been documented in the inner part of Orido Bay (Hatori 1977). The tsunami related to the 1707 Hoei earthquake along the northeastfacing coast of Miho Peninsula and the coastal area of the northern Shimizu Plain had estimated wave heights of $5 \mathrm{~m}$ and $4 \mathrm{~m}$, respectively (Hatori 1977).

\section{Methods}

We conducted ground-penetrating radar (GPR) surveys along three lines using an SIR-4000 unit (GSSI Co. Ltd, Nashua, NH, USA) with a $400 \mathrm{MHz}$ antenna, with a vertical resolution of $\sim 15 \mathrm{~cm}$ (Fig. 3). After acquisition, the GPR data was processed using the GSSI's software RADAN version 7.4.15. During the processing, the finite impulse response (FIR) filter was used to reduce the noise and the gain correction was used to improve the visibility of the data.

Sediment cores ( $7 \mathrm{~m}$ long and $6 \mathrm{~cm}$ in diameter) recovered at two sites in the study area (Fig. 2) were split longitudinally and logged according to lithology, sedimentary structures, and the presence of mollusks. X-ray radiographs were taken of slab samples $(6 \mathrm{~cm}$ wide $\times 20 \mathrm{~cm}$ long $\times 1 \mathrm{~cm}$ thick) from the split cores.

Grain size was measured using the wet-sieving method at 1-phi intervals in the range of -3 phi $(8 \mathrm{~mm})$ and 5 phi $(32 \mu \mathrm{m})$. A portion of the remaining subsamples was dried and ground following the removal of sandy grains. A $1 \mathrm{~N} \mathrm{HCI} \mathrm{solution} \mathrm{was} \mathrm{added} \mathrm{to} 10 \mathrm{mg}$ of sample in a 


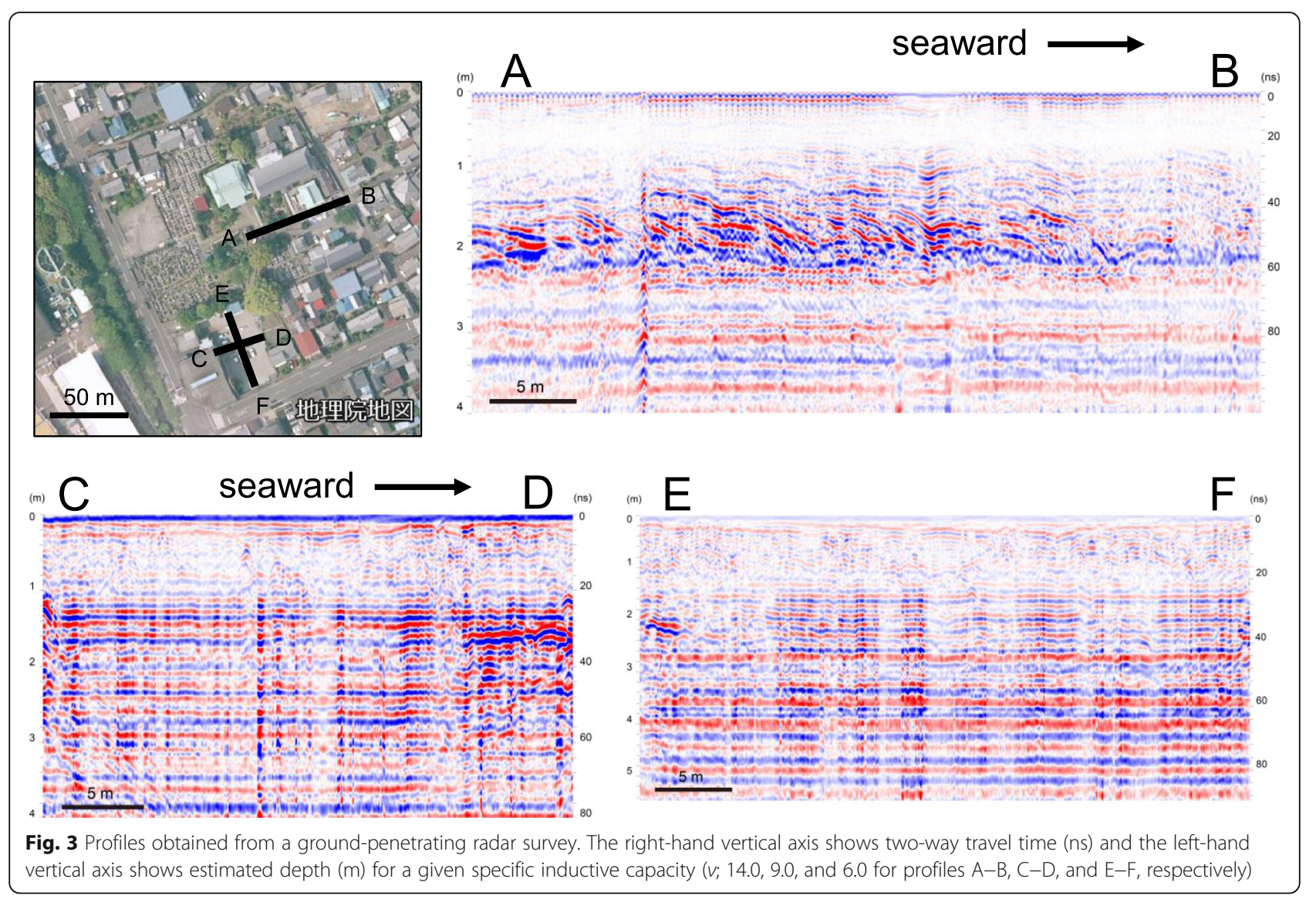

silver container to remove inorganic carbon, and the remaining sample was heated on a hot plate for $2 \mathrm{~h}$. Dried samples were placed in a tin container. The total sulfur content (TS) and the ratio of total organic carbon to TS (the $\mathrm{C} / \mathrm{S}$ ratio) were determined using a CHNS material analyzer (Flash 2000, Thermo Fisher Scientific). The accuracy of the procedure was controlled using the BBOT standard (2,5-Bis-(5-tert.-butyl-benzoxazol2-yl)-thiophen). As the $\mathrm{C} / \mathrm{S}$ ratio of muddy sediments is higher in freshwater than in marine (Berner and Raiswell 1984) and euxinic and brackish coastal waters (Leventhal 1983), C/S ratios have been used to distinguish between ancient marine and freshwater sedimentary deposits (Berner and Raiswell 1984; Kamei et al. 1997; Kitamura et al. 2019) (Fig. 4).

Foraminiferal tests were picked from the $>0.063 \mathrm{~mm}$ size fraction of core sediment samples. Taxonomic identification was based on Takata et al. $(2006,2016)$ and Charrieau et al. (2018). We calculated the number of specimens of the dominant taxa per gram of sediment. Transfer functions are commonly applied to coastal deposits for sea-level reconstruction (Horton et al. 1999); however, the very low abundance of foraminifera precluded the use of this technique in the present study.
Seventeen samples of well-preserved leaves and woody material were subjected to radiocarbon dating at Beta Analytic, using accelerator mass spectrometry (Table 1). The results were translated into the $2 \sigma$ calendar-year range using the program OxCal4.1 (Bronk Ramsey 2009), based on a comparison with IntCal13 data (Reimer et al. 2013).

\section{Results \\ GPR profile}

The GPR profile along the line A-B showed seaward dipping reflections between 1 and $2 \mathrm{~m}$ in depth (Fig. 3). It suggests that the depositional setting near site 1 corresponds to the seaward slope of the beach ridge. The reflection pattern indicates continuous progradation of the coastline to the northeast. Note that reflections below 2 $\mathrm{m}$ were not successfully resolved due to the presence of the water table, and burial of artificial objects is visible in the systematic reflection patterns near the surface. The GPR profile along the lines $\mathrm{C}-\mathrm{D}$ and $\mathrm{E}-\mathrm{F}$, which is shore-normal and shore-parallel directions, respectively, showed horizontal to sub-horizontal reflections below $1 \mathrm{~m}$ in depth (Fig. 3). It suggests a different sedimentary environment near site 2 


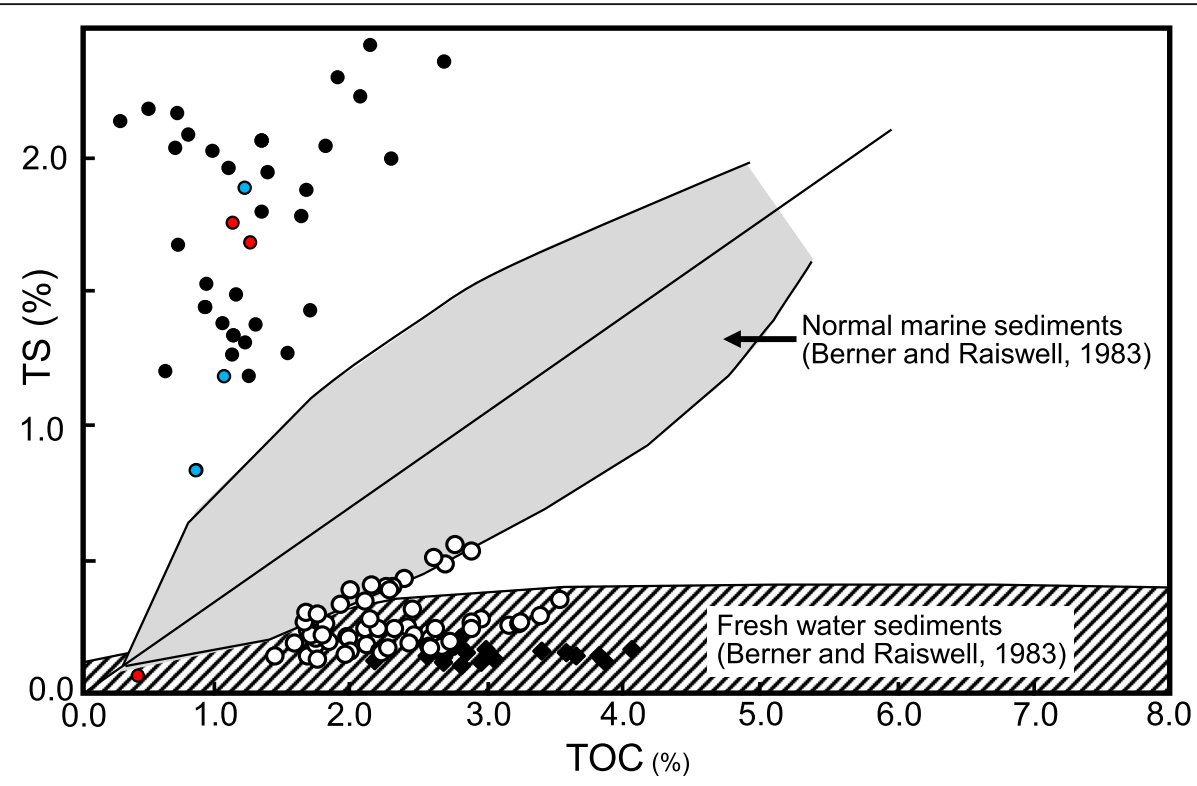

- Deposits of upper intertidal and supratidal zones in recent muddy tidal flat (Kitamura et al., 2019)

- Deposits of lower intertidal zone in recent muddy tidal flat (Kitamura et al., 2019)

- Deposits below $\mathrm{H}_{2} \mathrm{~S}$ water column in Black Sea (Leventhal, 1983)

- Site 1

o Site 2

Fig. 4 Scatter plots of TS versus TOC for the cored sediments, and marine and freshwater sediments

Table $1{ }^{14} \mathrm{C}$ ages of samples from the study area

\begin{tabular}{|c|c|c|c|c|c|c|c|c|}
\hline Sample no. & Site & Depth (m) & $\begin{array}{l}\text { Altitude } \\
\text { (m above m.s.l.) }\end{array}$ & Materials & $\delta^{13} \mathrm{C}(\% 0)$ & $\begin{array}{l}\text { Conventional }{ }^{14} \mathrm{C} \\
\text { age (year BP) }\end{array}$ & $\begin{array}{l}\text { Calibrated age } \\
\text { (20; cal. year BP; 95.4\%) }\end{array}$ & Beta ID \\
\hline 1 & 1 & 4.05 & 0.45 & Wood & -27.02 & $2050 \pm 30$ & $166 \mathrm{cal} \mathrm{BC}$ to $20 \mathrm{cal} \mathrm{AD}$ & 496227 \\
\hline 2 & 1 & 4.20 & 0.30 & Wood & -29.13 & $1650 \pm 30$ & 264-532 cal AD & 496228 \\
\hline 3 & 1 & 4.21 & 0.29 & Leaf & -30.08 & $1600 \pm 30$ & 398-539 cal AD & 502135 \\
\hline 4 & 1 & 4.21 & 0.29 & Leaf & -29.89 & $1740 \pm 30$ & 236-386 cal AD & 502136 \\
\hline 5 & 1 & 4.53 & -0.03 & Wood & -26.34 & $2080 \pm 30$ & $191-38$ cal BC & 496229 \\
\hline 6 & 1 & 6.47 & -1.97 & Plant material & -26.21 & $2380 \pm 30$ & 726-392 cal BC & 517951 \\
\hline 8 & 2 & 2.10 & 1.70 & Leaf & -29.52 & $1670 \pm 30$ & $258-428$ cal AD & 502137 \\
\hline 9 & 2 & 2.10 & 1.70 & Leaf & -29.46 & $1740 \pm 30$ & 236-386 cal AD & 502138 \\
\hline 10 & 2 & 3.66 & 0.14 & Plant material & -28.80 & $2120 \pm 30$ & $345-50$ cal BC & 508311 \\
\hline 11 & 2 & 3.67 & 0.13 & Wood & - & $3430 \pm 40$ & $1877-1636 \mathrm{cal} \mathrm{BC}$ & 503648 \\
\hline 12 & 2 & 4.64 & -0.84 & Plant material & -22.42 & $3110 \pm 30$ & $1437-1288 \mathrm{cal} \mathrm{BC}$ & 508312 \\
\hline 13 & 2 & 4.87 & -1.07 & Plant material & -24.63 & $2530 \pm 30$ & $797-543$ cal BC & 508313 \\
\hline 14 & 2 & 4.98 & -1.18 & Plant material & -28.50 & $3040 \pm 30$ & $1397-1216 \mathrm{cal}$ BC & 508314 \\
\hline 15 & 2 & 5.20 & -1.40 & Plant material & -27.7 & $2420 \pm 30$ & $748-402$ cal BC & 517953 \\
\hline 16 & 2 & 5.34 & -1.54 & Plant material & -24.6 & $2680 \pm 30$ & $897-802$ cal BC & 517954 \\
\hline 17 & 2 & 5.51 & -1.71 & Plant material & -27.1 & $2940 \pm 30$ & $1257-1043 \mathrm{cal} \mathrm{BC}$ & 517955 \\
\hline
\end{tabular}


comparing with that near site 1 . Note that reflections above $1 \mathrm{~m}$ in depth was chaotic, which may correspond to landfills.

\section{Sedimentary facies}

We classified the borehole sediments into three facies on the basis of lithology, grain size, color, sedimentary structures, and fossil (Fig. 5; Appendixes 1 and 2).

Facies A is composed of massive, bluish-gray mediumgrained sand and shows a fining-upward trend (Figs. 4, 5, 6 and 7). The lowest part of the borehole sediments contains plant materials and shells of the mollusks Umbonium moniliferum and Batillaria cumingii (Fig. 8). The relative abundance of mollusk shells shows an upward decrease within the facies. A few individuals of benthic foraminifera were found, which were Ammonia spp., Elphidium advenum, and Pseudononion japonicum (Fig. 8, Table 2).
The relative abundance of $P$. japonicum shows an upward decrease and increase in sites 1 and 2, respectively (Fig. 8).

Facies B consists of laminated clay and graded sand beds $(<10 \mathrm{~cm}$ thick) (Fig. 5), and overlies Facies A. The facies contains plant materials, but no mollusks or foraminifera (Fig. 8). The TS content and C/S ratio in the clay are $1-2 \%$ and $\sim 0.7$, respectively (Fig. 8 ). Clay (< $32 \mu \mathrm{m}$ ) contents are 70-80\% (Figs. 6 and 7). The youngest ${ }^{14} \mathrm{C}$ age from the clay is $\mathrm{AD} 398$ to 539 , obtained from a sample of a leaf (Fig. 5, Table 1).

Facies C consists of alternating sand and clastsupported gravel beds and occupies the uppermost part of the borehole sediments. The base comprises a layer $(10 \mathrm{~cm}$ thick) of massive to weakly laminated finegrained sand, and it overlies Facies B across a sharp boundary. This facies contains mud clasts and woody material, but no mollusks or foraminifera. At site 2, a woody debris bed was identified at a depth of 2.04-2.10 m

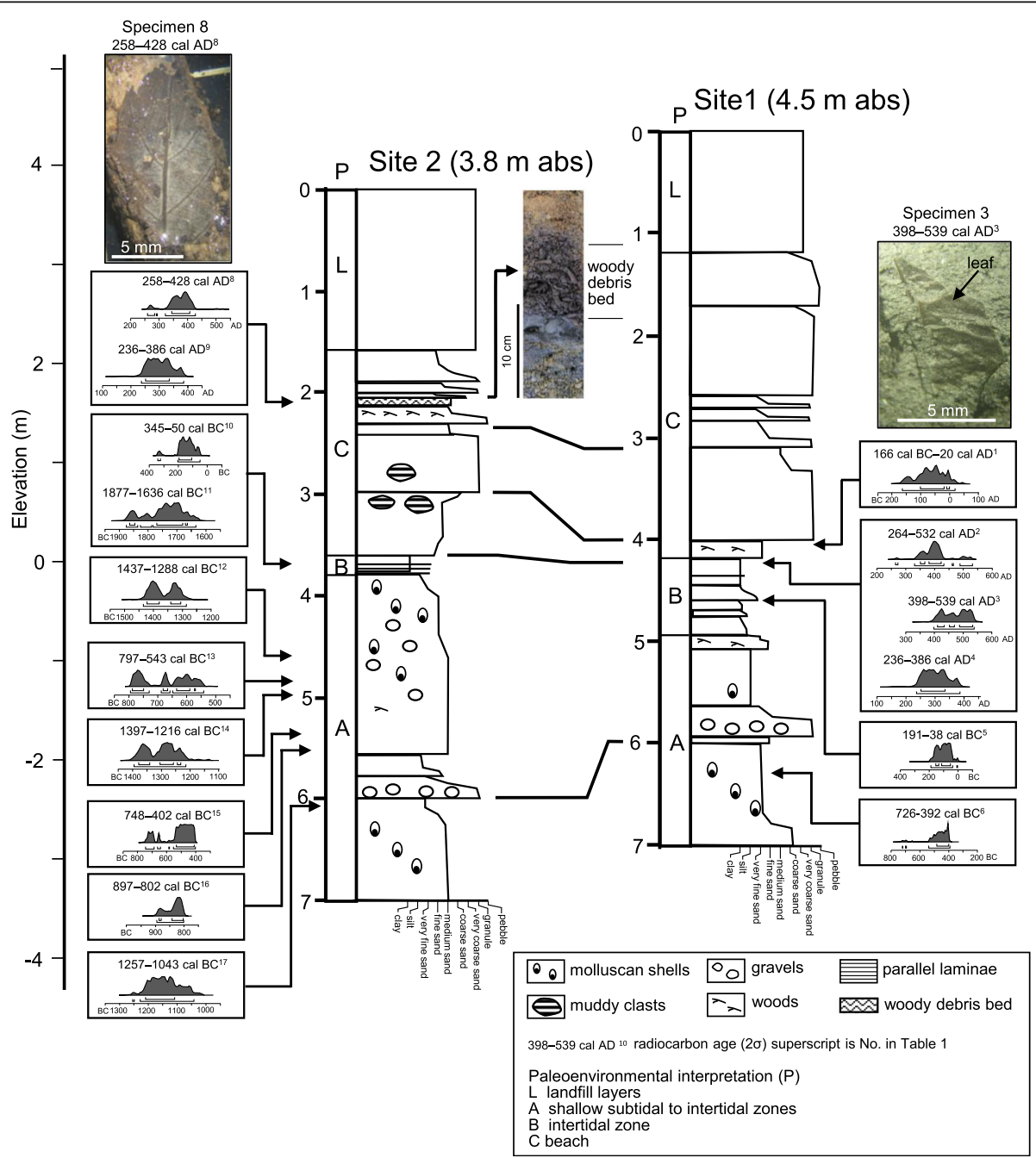

Fig. 5 Columnar sections of two sediment cores collected at the study area, showing two specimens of leaf materials (specimens 3 and 8). Details of radiocarbon dating reported are provided in Table 1 


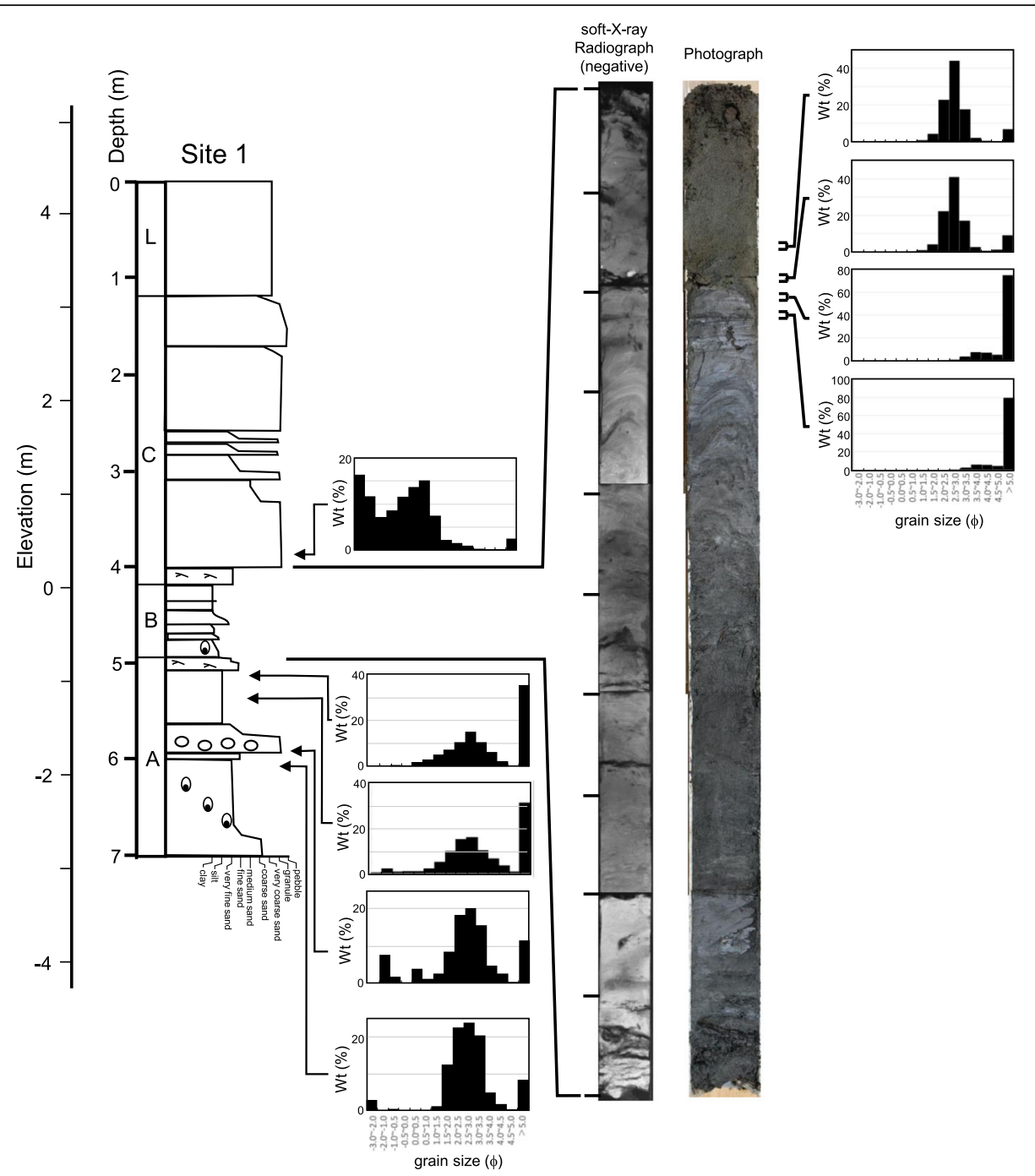

Fig. 6 Grain-size distribution of cored sediments at site 1. See Fig. 5 for legend

(Figs. 5 and 7). Leaf material in this bed yielded ${ }^{14} \mathrm{C}$ ages of AD 258 to 428 (Fig. 4, Table 1). GPR reflections show parallel to seaward dipping layers that indicate progradation of the beach ridge and shoreline (Fig. 3).

Table $\mathbf{2}$ List of foraminifera from cored sediment samples

\begin{tabular}{lcccccccc}
\hline Site & 1 & & & & & \\
\cline { 3 - 4 } \cline { 6 - 8 } Depth (m) & 5.505 & 5.955 & 6.105 & & 3.955 & 4.555 & 6.205 \\
\hline Ammonia spp. & 6 & 3 & 2 & & 7 & 3 & 2 \\
Bolivina sp. & & & & & & 2 \\
Elphidium advenum & & 2 & 6 & & 15 & & \\
Elphidium somaense & & & 2 & & 6 & & \\
Pseudononion japonicum & & 4 & 9 & & 8 & 4 & \\
Pseudononion sp. A & & & & & & \\
Unidentified & 1 & & & & & \\
Sediment (g) & 6.7 & 9.0 & 10.1 & & 8.1 & 7.9 & 6.0 \\
\hline
\end{tabular}

\section{Discussion}

Facies A contains shells of the mollusks $U$. moniliferum and $B$. cumingii, which inhabit the intertidal to shallow subtidal zones in tidal flats (Okutani 2000) (Fig. 8). A few individuals of benthic foraminifera Ammonia spp., Elphidium advenum, and Pseudononion japonicum were found in Facies A (Fig. 5). Ammonia spp. are generally found in the innermost bay regions and brackish water (e.g., Matsubara, 1989; Kosugi et al. 1991; Kitamura et al. 2019), and Elphidium advenum and Pseudononion japonicum inhabit the sublittoral zone (Akimoto and Hasegawa, 1989; Oki, 1989). As such, we interpret Facies A to have been 


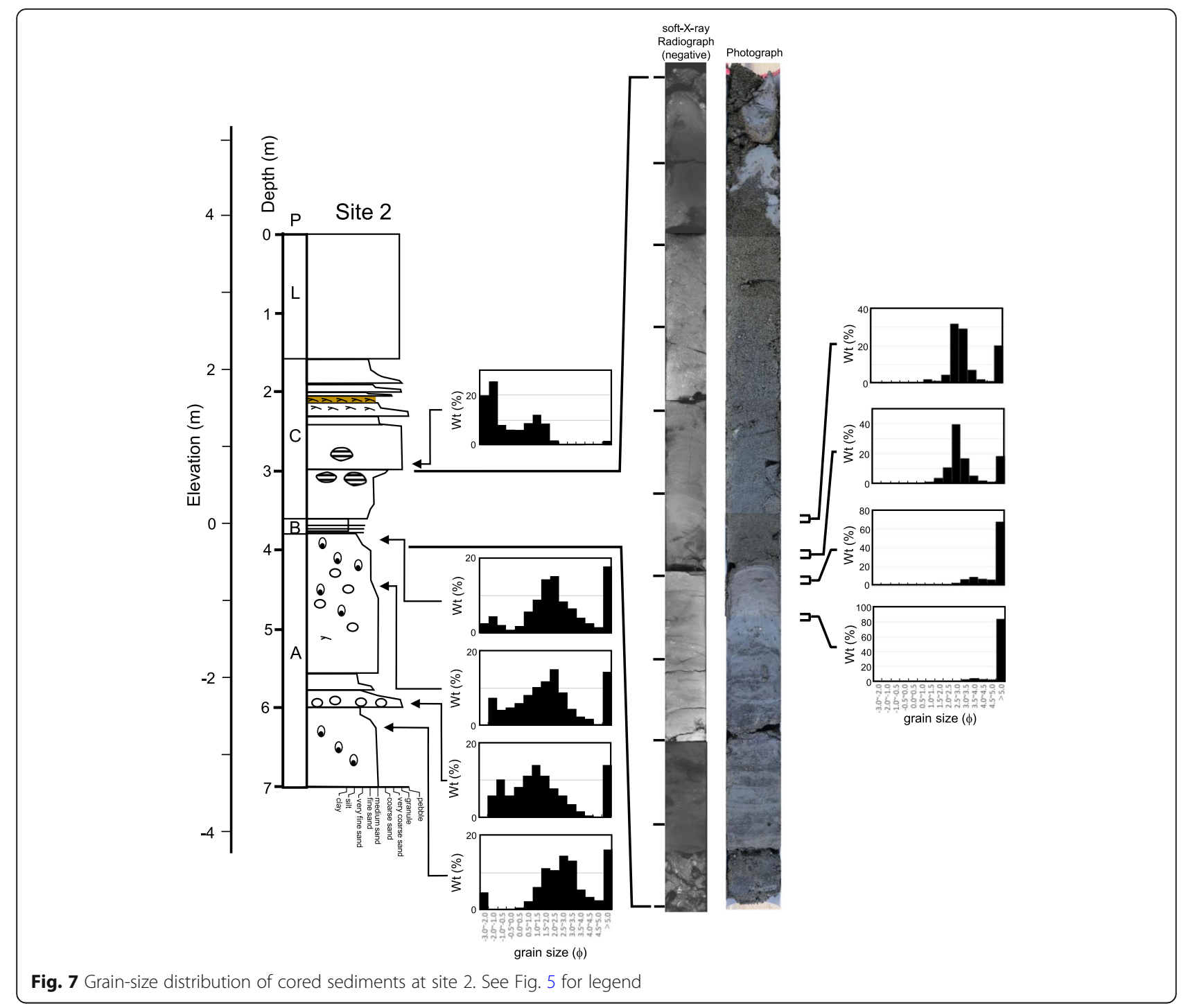

deposited in a sandy marine environment, representative of the intertidal to shallow subtidal zones. According to Nomura and Seto (1992), Pseudononion japonicum prefers salinities of $>25 \%$. The difference in the relative abundance of $P$. japonicum at sites 1 and 2 might indicate movement of the river mouth over time.

The preservation of laminations and absence of mollusks and foraminifer shells in Facies B indicate deposition in euxinic bottom water. The $\mathrm{C} / \mathrm{S}$ value of the clay $(\sim 0.7)$ is consistent with that of deposits in euxinic and brackish coastal water, such as the Black Sea (Leventhal 1983), and is much lower than those of intertidal mudflat deposits (4.9-11.4) (Kitamura et al. 2019). This indicates that Facies B was deposited under euxinic and stagnant conditions below the intertidal zone. As the mean tide range at Shimizu Port is $1.6 \mathrm{~m}$, the water depth of Facies B was estimated to be greater than -0.8 $\mathrm{m}$. The very low TS content $(0.1 \%)$ and high $\mathrm{C} / \mathrm{S}$ ratio
(6.3) in the uppermost part of Facies B at site 1 might reflect alteration resulting from the seepage of groundwater from the overlying Facies $C$.

Facies $\mathrm{C}$ is characterized by alternating sand and clastsupported gravel beds and the occurrence of mud clasts. These features indicate a sedimentary environment characterized by high-energy hydrodynamic conditions. According to Kennedy and Woods (2012), wood debris beds on gravel-dominated beaches can be deposited during high wave events and are located at the top of the storm berm. It is therefore likely that Facies $C$ was deposited in a backshore or beach ridge environment at an elevation of $>0.8 \mathrm{~m}$, which corresponds to the sea level at high tide.

The vertical facies succession suggests the sedimentary environment changed from intertidal to shallow subtidal zones (Facies A), through a euxinic subtidal zone (Facies B), and then to a beach area (Facies $C$ ), 


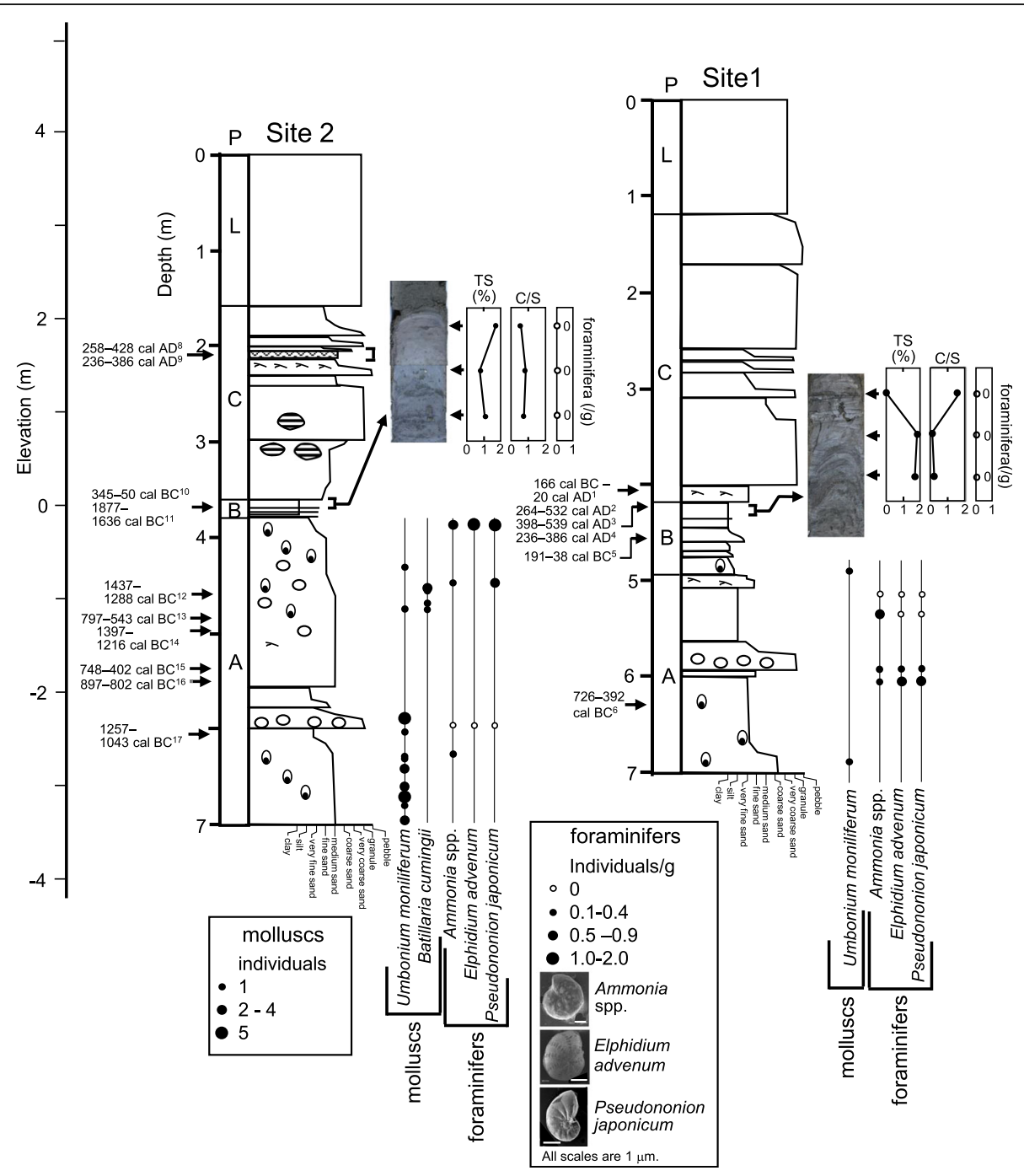

Fig. 8 Stratigraphic distributions of the dominant species of mollusk fossils, total sulfur content (TS), ratio of total organic carbon to TS (i.e., the C/ $\mathrm{S}$ ratio), and foraminifera in cored deposits at sites 1 and 2. See Fig. 5 for legend

indicating a sea-level rise followed by a drop. Radiocarbon dating shows that the sea-level rise took place between $1257 \mathrm{cal} \mathrm{BC}$ and $400 \mathrm{cal} \mathrm{AD}$. Tanabe et al. (2016) estimated about $2 \mathrm{~m}$ of relative sea-level rise during $1000-0$ cal BC based on the analysis of sedimentary records around Kanto Plain, central Japan. However, eustatic sea level was likely stable during that time (Sloss et al. 2007; Woodroffe et al. 2012). As noted above, the mean subsidence rate is $6.3 \mathrm{~mm} /$ year in the Shimizu area. With the duration of the depositional event assumed to be 1660 years (i.e., between $1257 \mathrm{cal}$ $\mathrm{BC}$ and $400 \mathrm{cal} \mathrm{AD}$ ), the mean sedimentation rate is estimated to be about $1.2 \mathrm{~mm}$ /year. We therefore interpret that the sea-level rise during the deposition of Facies A-B was caused mainly by local subsidence (Fig. 9).

Of note, the abrupt change from the subtidal zone (below $-0.8 \mathrm{~m}$ ) to beach conditions (above $0.8 \mathrm{~m}$ ) is indicated by lithofacies changes from Facies B to C, with an absence of intertidal Facies A. The fall in relative sea level is estimated to have been up to $1.6 \mathrm{~m}$ (Fig. 9). The youngest ${ }^{14} \mathrm{C}$ age within Facies B is $\mathrm{AD} 398-539$, derived from leaf material (specimens 3), while the oldest ${ }^{14} \mathrm{C}$ age within Facies $C$ is AD 258-428, also derived from leaf material (specimen 8) (Fig. 5). As these specimens are thin and delicate leaves, their very well-preserved condition (Fig. 5) indicates that they have not been reworked from older deposits. As such, based on the ${ }^{14} \mathrm{C}$ ages of these specimens, we estimate that sea level fell during the period AD 398-428.

There are no reports of eustatic sea-level decreases at this time; however, Sangawa (2001, 2013) (Fig. 1) reported evidence for intense shaking in west Shizuoka Prefecture during the early fourth century (segment $\mathrm{D}$ ). The present study area experienced $1.2 \mathrm{~m}$ of coseismic uplift during the 1854 

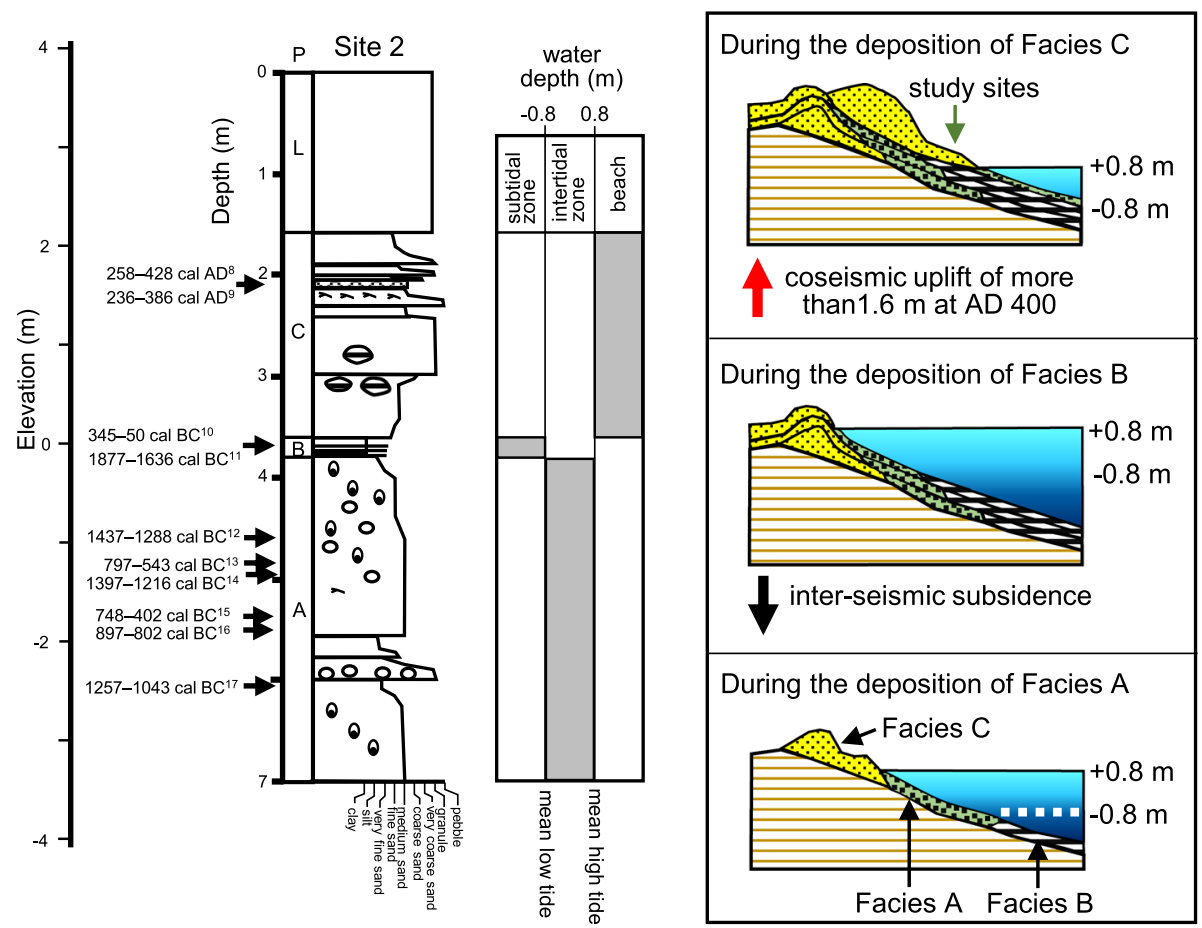

Fig. 9 Reconstruction of water-depth changes and depositional environments in the study area (Shimizu, central Japan) for the periods before and after the AD 400 earthquake

Ansei-Tokai earthquake (Kitamura and Kobayashi 2014). We therefore propose that the fall in relative sea level was caused by coseismic uplift associated with the rupture of segment E, possibly during the AD 400 earthquake (Fig. 9). As the base of Facies $C$ is located at mean sea level, the total subsidence was at least $0.8 \mathrm{~m}$ greater than the uplift caused by the coseismic uplift events after the $\mathrm{AD} 400$ earthquake.

This study did not identify a tsunami deposit associated with the $\mathrm{AD} 400$ event, for which there are two potential explanations. The first is that Miho Peninsular reduced the tsunami's energy. Indeed, no tsunami associated with the 1854 Ansei-Tokai earthquake has been documented in the inner part of Orido Bay, even though the wave height of the tsunami along the coastal area of the northern Shimizu Plain is estimated to have been $3 \mathrm{~m}$ (Hatori 1977). The second explanation is that an earthquake nucleating in segment $\mathrm{E}$ might induce significant uplift but does not cause a large tsunami because the segment is located too close to the shore.

Sangawa $(2001,2013)$ postulated that a large earthquake occurred around AD 400 within segment B, as inferred from slope failure at Akatsuchiyama mound tomb (Fig. 1). Therefore, it is thought that megathrust ruptures of segments B-E occurred simultaneously or within a few years of each other at $\sim \mathrm{AD} 400$. The interval between the AD 400 and 684 Hakuho earthquakes is about 280 years, slightly longer than the average interval of 220-230 years between events that occurred between the $\mathrm{AD} 684$ and 1361 earthquakes. The data from this study show that segment E ruptured during the 1854 Ansei-Tokai, 1361 Shohei Tokai, and AD 400 earthquakes, and that the recurrence interval varies from about $500-1000$ years.

\section{Conclusion}

To clarify the history of megathrust earthquakes along the Suruga Trough, central Japan, we studied the sediment, fossil contents, and the $\mathrm{C} / \mathrm{S}$ ratio of two sediment cores collected at Kaichoji Temple, which was built in AD 1011 on a beach ridge in the coastal area of the Shimizu Plain, which is protected from the open sea by the Miho Peninsula. The results can be summarized as follows:

1. We identified three sedimentary facies: Facies 1 (intertidal to shallow subtidal zones), Facies 2 (stagnant conditions below the intertidal zone), and Facies 3 (backshore and beach ridge). A sharp boundary between Facies 2 and the overlying Facies 3 at $0.20-0.25 \mathrm{~m}$ above sea level indicates a rapid fall in relative sea level of $1.6 \mathrm{~m}$ at AD 398-428.

2. The age of the boundary between Facies 2 and Facies 3 corresponds to the timing of a large earthquake in west Shizuoka Prefecture around AD 400. The abrupt change in the sedimentary environment was possibly related to coseismic uplift caused by a megathrust rupture along the Suruga Trough. 


\section{Appendix 1}

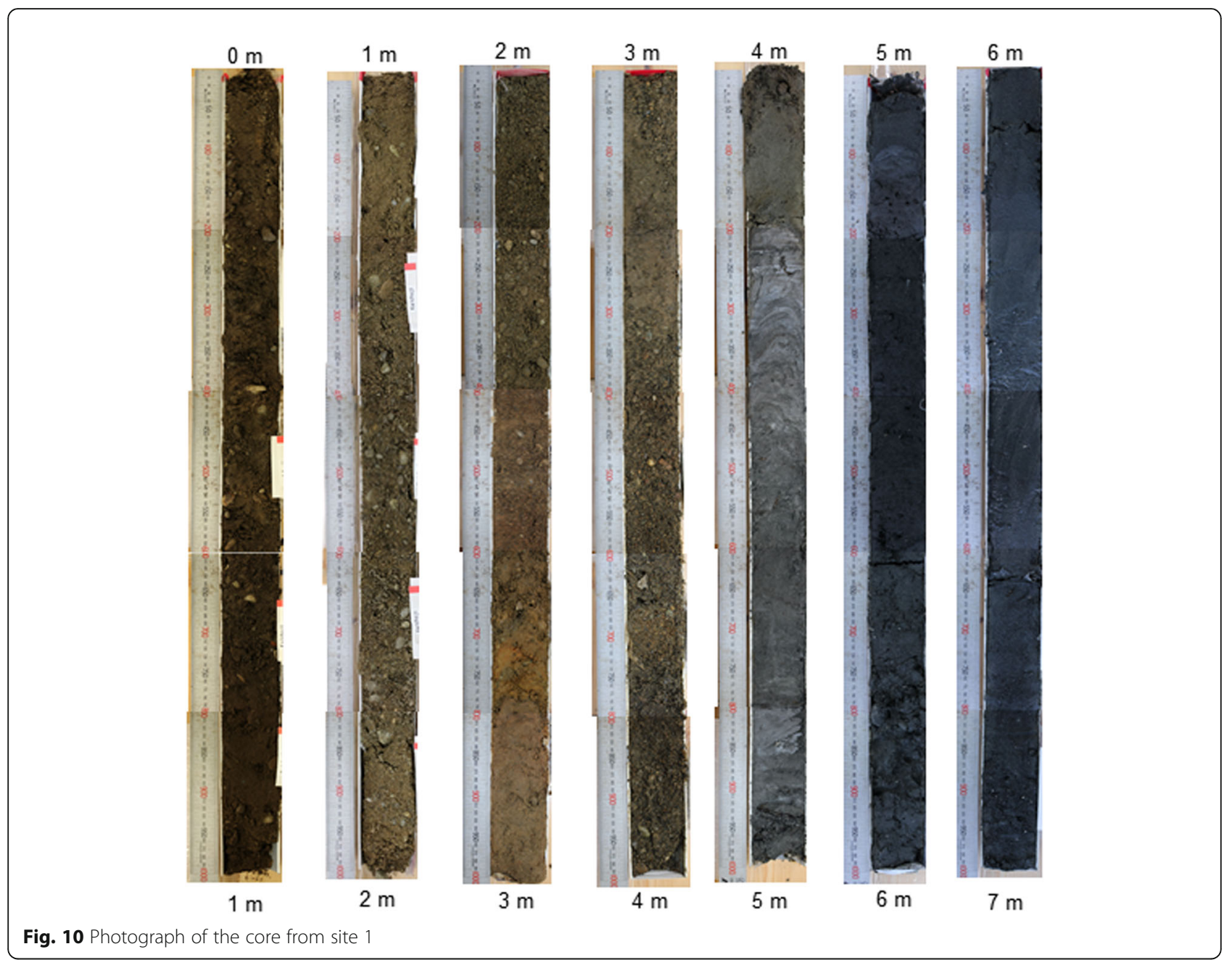




\section{Appendix 2}

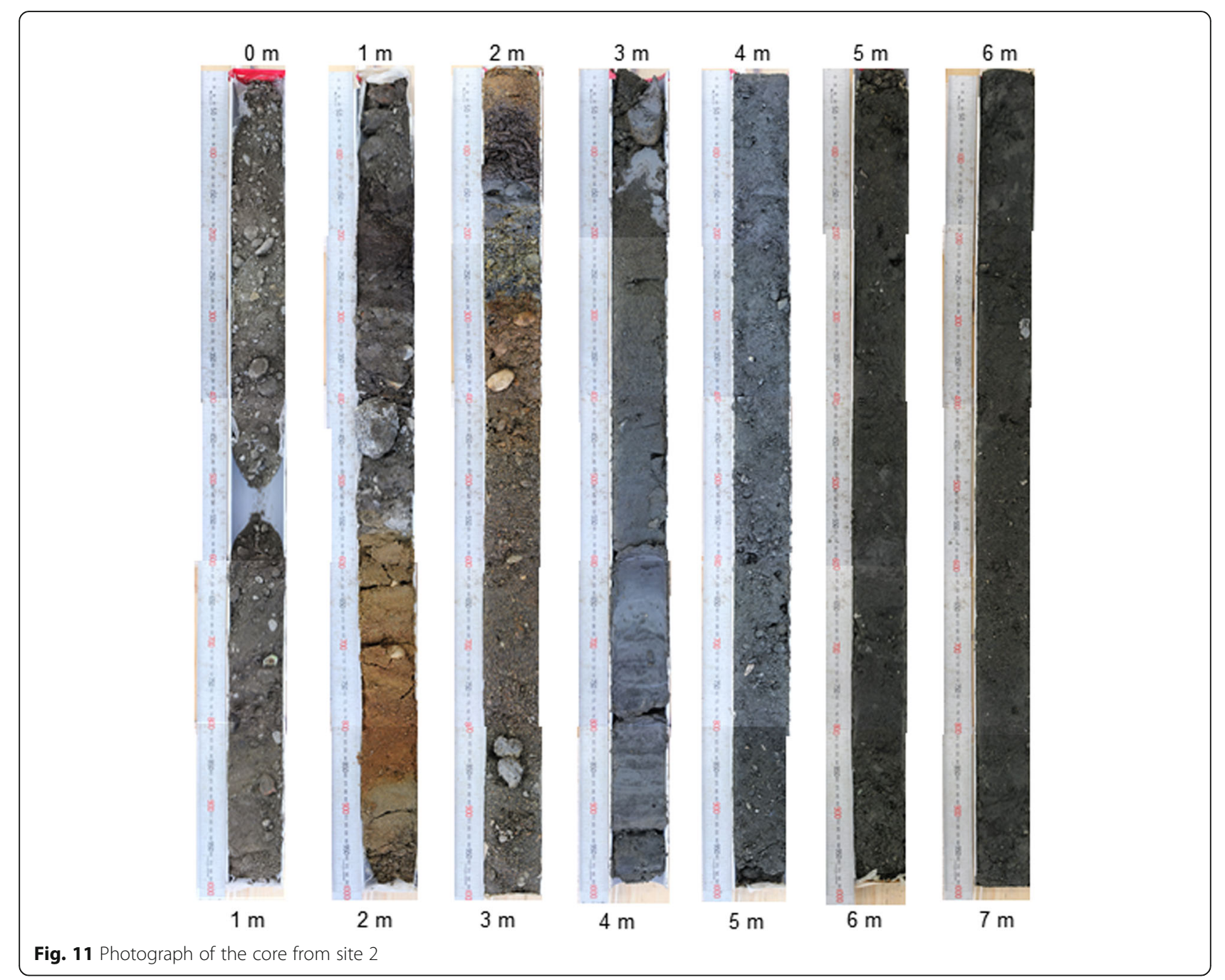

\section{Acknowledgements}

We thank two anonymous reviewers whose constructive comments significantly helped to improve this paper. We thank landowner in the study area for allowing us access to the land for our research activities.

\section{Authors' contributions}

AK conceived the study designed, collected samples, and identified specimens of foraminiferal samples. TI, DSuz, TK, and AA analyzed cored sediments, conducted grain-size analysis, and identified mollusk samples. KY analyzed total sulfur contents and the ratio of total organic carbon to TS. DSug conducted ground-penetrating radar (GPR) surveys. All authors read and approved the final manuscript.

\section{Funding}

This study was funded by "Future Scientists' School in Shizuoka University", a special program supported by JST, the Japan Science and Technology Agency, a Grant-in-Aid (17H02074) from the Japan Society for the Promotion of Science, and the Center for Integrated Research and Education of Natural Hazards, Shizuoka University.

Availability of data and materials

Please contact the corresponding author for data requests.

\section{Competing interests}

The authors declare that they have no competing interests.

\section{Author details}

${ }^{1}$ Faculty of Science, Shizuoka University, 836 Ohya, Suruga-ku, Shizuoka 422-8529, Japan. ${ }^{2}$ Center for Integrated Research and Education of Natural hazards, Shizuoka University, 836 Ohya, Suruga-ku, Shizuoka 422-8529, Japan. ${ }^{3}$ Iwata Minami High School, 3084 Mitsuke, Iwata City, Shizuoka Prefecture 438-8686, Japan. ${ }^{4}$ Museum of Natural and Environmental History, Shizuoka, 5762 Ohya, Suruga-ku, Shizuoka City, Shizuoka Prefecture 422-8017, Japan.

Received: 8 April 2019 Accepted: 1 August 2019

Published online: 19 August 2019

\section{References}

Akimoto K, Hasegawa S (1989) Bathymetric distribution of the recent benthic foraminifers around Japan: as a contribution to the new paleobathymetric scale. In Kitamura N, Otsuki K and Ohguchi T. (eds.) Cenozoic Geotectonics of Northeast Honshu Arc. Geol. Soc. Jpn. Mem. 58:229-240.

Ando M (1975a) Possibility of a major earthquake in the Tokai district, Japan and its pre-estimated seismotectonic effects. Tectonophysics 25:69-85 
Ando M (1975b) Source mechanisms and tectonic significance of historical earthquakes along the nankai trough, Japan. Tectonophysics 27:119-140

Ando M, Kitamura A, Tu Y, Ohashi Y, Imai T, Nakamura M, Ikuta R, Miyairi Y, Yokoyama Y, Shishikura M (2018) Source of high tsunamis along the southernmost Ryukyu trench inferred from tsunami stratigraphy. Tectonophysics. 722:265-276

Atwater BF (1987) Evidence for great Holocene earthquakes along the outer coast of Washington State. Science 236:942-944

Berner RA, Raiswell R (1984) C/S method for distinguishing freshwater from marine sedimentary rocks. Geology 12:365-368

Bronk Ramsey C (2009) Bayesian analysis of radiocarbon dates. Radiocarbon 51(1): 337-360

Central Disaster Management Council (2011) Report of the committee for technical investigation on countermeasures for earthquakes and tsunamis based on the lessons learned from the "2011 off the Pacific coast of Tohoku earthquake." http://www.bousai.go.jp/kaigirep/chousakai/tohokukyokun/pdf/ Report.pdf Accessed 26 Jan 2017.

Charrieau LM, Filipsson HL, Nagai Y et al (2018) Decalcification and survival of benthic foraminifera under the combined impacts of varying $\mathrm{pH}$ and salinity. Mar Environ Res 138:36-45

Coordinating Committee for Earthquake Prediction (2018). 1-3 Crustal Deformations of Entire Japan. http://cais.gsi.go.jp/YOCHIREN/report/ kaihou99/01_03.pdf

Fujiwara O, Hirakawa K, Irizuki T et al (2010) Millennium-scale recurrent uplift inferred from beach deposits bordering the eastern Nankai Trough, Omaezaki area, central Japan. Island Arc 19:374-388

Furumura T, Imai K, Furumura T et al (2011) A revised tsunami source model for the 1707 Hoei earthquake and simulation of tsunami inundation of Ryujin Lake, Kyushu, Japan. Jour Geophy Res Solid Earth 116:B02308

Goto K, Hongo C, Watanabe M et al. (2018) Large tsunamis reset growth of massive corals Prog Earth Planet Sci 4:42 DOl.org/10.1186/s40645-019-0265-2

Hatori T (1975) Sources of large tsunamis generated in the Boso, Tokai and Nankai Regions in 1498 and 1605. Bull Earthq Res Inst Univ 50:171-185 (in Japanese with English abstract

Hatori T (1976) Documents of tsunami and crustal deformation in Tokai district associated with the Ansei earthquake of Dec. 23, 1854. Bull Earthq Res Inst Univ 51:13-28 (in Japanese with English abstract

Hatori T (1977) Field Investigation of the Tokai Tsunamis in 1707 and 1854 along the Shizuoka Coast. Bull Earthq Res Inst Univ 52:407-439 (in Japanese with English abstract

Hayward BW, Cochran U, Southall K et al (2004) Micropaleontological evidence for Holocene earthquake history of the eastern Bay of Plenty, New Zealand, and a new index for determining the land elevation record. Quat Sci Rev 23: $1651-1667$

Horton BP, Edwards RJ, Lloyda JM (1999) Reconstruction of former sea levels using a foraminiferal-based transfer function. Jour Foram Res 29:117-129

Inoue T, Goto K, Nishimura Y, Watanabe M, lijima Y, Sugawara D (2017) Paleotsunami history along the northern Japan Trench: evidence from Noda Village, northern Sanriku coast, Japan. Prog Earth Planet Sci 4:42 https://doi. org/10.1186/s40645-017-0158-1

Iryu Y, Maemoku H, Yamada T et al (2009) Limestones as a paleobathymeter for reconstructing past seismic activities: Muroto-misaki, Shikoku, southwestern Japan. Glob Planet Chang 66:52-64

Ishibashi K (1976) Re-examination of a great earthquake expected in the Tokai district: possibility of the «Suruga Bay earthquake», Abstracts, Seismol Soc Japan 1976 (2):30-34 (in Japanese)

Ishibashi K (1984) Coseismic vertical crustal movements in the Suruga Bay region. The Quaternary Research (Daiyonki-kenkyu) 23:105-110 (in Japanese with English Abstract).

Ishibashi K, Satake K (1998) Problems of forecasting great earthquakes in the subduction zones around Japan by means of paleoseismology. J Seismol Soc Japan (Zisin) 50:1-21 (in Japanese with English Abstract).

Ishibashi K (2004) Status of historical seismology in Japan. Ann Geophys 47:339-368

Ishibashi K (2014) Great Nankai-trough Earthquake-History, Science, Societ. Iwanami Shoten 205p

Ishihara T, Mizuno K (2016) Shallow geological structure in the coastal area of the northern Suruga Bay, Japan. In Seamless Geoinformation of Coastal Zone, "Northern Coastal Zone of Suruga Bay", Seamless Geological Map of Coastal Zone S-5. Geological Survey of Japan, AIST 1-24 (in Japanese, with English abstract).
Ishimura D, Miyauchi T (2015) Historical and paleo-tsunami deposits during the last 4000 years and their correlations with historical tsunami events in Koyadori on the Sanriku Coast, northeastern Japan. Prog Earth Planet Sci 2: 16. https://doi.org/10.1186/s40645-015-0047-4

Kamei T, Tokuoka T, Sampei Y et al (1997) Geotechnology and sedimentary environment of holocene deposits in the Matsue plains. Jour Jpn Soc Eng Geol 38:280-295

Kennedy DM, Woods JLD (2012) The influence of coarse woody debris on gravel beach geomorphology. Geomorphology 159-160:106-115

Kitamura A (2016) Examination of the largest-possible tsunamis (Level 2 tsunami) generated along the Nankai and Suruga troughs during the past 4000 years based on studies of tsunami deposits from the 2011 Tohoku-oki tsunami. Prog Earth Planet Sci 3:12 https://doi.org/10.1186/s40645-016-0092-7

Kitamura A, Imai T, Mitsui Y et al (2017) Late Holocene uplift of the Izu Islands on the northern Zenisu Ridge off Central Japan. Prog Earth Planet Sci https:// doi.org/10.1186/s40645-017-0146-5

Kitamura A, Ito M, Ikuta R et al (2018a) Using molluscan assemblages from paleotsunami deposits to evaluate the influence of topography on the magnitude of late Holocene mega-tsunamis on Ishigaki Island, Japan. Prog Earth Planet Sci 5(41) https://doi.org/10.1186/s40645-018-0200-y

Kitamura A, Kobayashi K (2014) Geologic evidence for prehistoric tsunamis and coseismic uplift during the AD 1854 Ansei-Tokai earthquake in Holocene sediments on the Shimizu Plain, central Japan. The Holocene 24:814-827

Kitamura A, Koyama M, Itasaka K et al (2014) Abrupt Late Holocene uplifts of the southern. Izu Peninsula, central Japan: evidence from emerged marine sessile assemblages. Island Arc 23:51-61

Kitamura A, Ohashi Y, Ishibashi H et al (2015) Holocene geohazard events on the southern Izu Peninsula, central Japan. Quat Int 397:541-554

Kitamura A, Seki Y, Kitamura Y et al (2018b) The discovery of emerged boring bivalves at Cape Omaezaki, Shizuoka, Japan: evidence for the AD 1361 Tokai earthquake along the Nankai Trough. Mar Geol 405:114-119

Kitamura A, Yamamoto Y, Yamada K et al (2019) Combined analysis of sulfur and carbon contents, and foraminifer as paleoenvironmental indicators in tidal flat sediments on Miura Peninsula, Japan. Estuar Coast Shelf Sci 226(106):256 https://doi.org/10.1016/j.ecss.2019.106256

Komori J, Shishikura M, Ando R et al. (2017) History of the great Kanto earthquakes inferred from the ages of Holocene marine terraces revealed by a comprehensive drilling survey. Earth Planet Science Letters 471:74-84.

Kosugi M, Kataoka H, Hasegawa S (1991) Classification of foraminifer communities as indicators of environments in an inner bay and its application to reconstruction of paleoenvironments. Fossils (Pala Soc Japan) 50:37-55 (in Japanese with English abstract

Kuroki H, Ito H, Takayama H et al (2004) 3-D simulation of the occurrence of slow slip events in the Tokai region with a rate-and state dependent friction law. Bull Seismol Soc Am 94:2037-2050

Leventhal JS (1983) An interpretation of carbon and sulfur relationships in Black Sea sediments as indicators of environments of deposition. Geochim Cosmochim Acta 47:133-137

Mannen K, Yoong KH, Suzuki S et al (2018) History of ancient megathrust earthquakes beneath metropolitan Tokyo inferred from coastal lowland deposits. Sediment Geol 364:258-275

Matsubara A (1989) Geomorphic development of barriers in the coastal lowlands during the Holocene -a case study of the lowlands along the Suruga Bay, Central Japan-. Geograp Rev Japan, series A, Chirigaku Hyoron 62(2):160-183 (in Japanese, with English abstract).

Minoura K, Imamura F, Sugawara D, Kono Y, Iwashita T (2001) The 869 Jogan tsunami deposit and recurrence interval of large-scale tsunami on the Pacific coast of northeast Japan. J Nat Dis Sci 23:83-88

Mogi K (1984/1985) Temporal variation of crustal deformation during the days preceding a thrust-type great earthquake-The 1944 Tonankai earthquake of Magnitude 8 1. Japan. Pure appl Graphrs 122:765-780

Monecke K, Finger W, Klarer D, Kongko W, McAdoo BG, Moore AL, Sudrajat SU (2008) A 1000-year sediment record of tsunami recurrence in northern Sumatra. Nature 455:1232-1234

Nanayama F, Satake K, Furukawa R, Shimokawa K, Atwater BF, Shigeno K, Yamaki S (2003) Unusually large earthquakes inferred from tsunami deposits along the Kuril trench. Nature 424:660-663

Nelson AR, Jennings AE, Kashima K (1996a) An earthquake history derived from stratigraphic and microfossil evidence of relative sea-level change at Coos Bay, southern coastal Oregon. Geol Soc Am Bull 108:141-154 
Nelson AR, Shennan I, Long A (1996b) Identifying coseismic subsidence in tidalwetland stratigraphic sequences at the Cascadia subduction zone of western North America. J Geophys Res 101(B3):6115-6135

Nomura R, Seto K (1992) Benthic foraminifera from brackish Lake Nakaumi, San-in District, southwestern Honshu, Japan. In: Ishizaki K, Saito T (eds) Centenary of Japanese. Micropaleontology. Terra Scientific Publishing Company, Tokyo, pp $227-240$

Oki K (1989) Ecological analysis of benthonic foraminifera in Kagoshima Bay, South Kyushu, Japan. South Pacific Study 10:1-191

Okutani T (2000) Marine Mollusks in Japan. University of Tokyo Press, 1173 pp.

Reimer PJ, Bard E, Bayliss A et al (2013) IntCal13 and Marine13 radiocarbon age calibration curves 0-50,000 years cal BP. Radiocarbon 55(4):1869-1887

Rubin CM, Horton BP, Sieh K et al (2017) Highly variable recurrence of tsunamis in the 7400 years before the 2004 Indian Ocean tsunami. Nat Commun 8: 16019. https://doi.org/10.1038/ncomms16019

Sangawa A (2001) Recent results of paleoseismological study based on earthquake traces excavated at archeological sites. Ann Rep Active Fault and Paleoearthquake Res 1:287-300 (in Japanese)

Sangawa A (2013) Research results of earthquake-archeology. The Quat Res (Daiyonki-Kenkyu) 52:191-202 (in Japanese)

Satake K, Atwater BF (2007) Long-term perspectives on giant earthquakes and tsunamis at subduction zones. Annu Rev Earth Planet Sci 35:349-374

Sato H (1977) Precursory land tilt prior to the Tonankai earthquake of 1944. In some precursors prior to recent great earthquakes along the Nankai trough. J Phys Earth 25:S115-S121

Sawai Y, Satake K, Kamataki T et al (2004) Transient uplift after a seventeenth century earthquake along the Kuril subduction zone. Science 306:1918-1920

Shimazaki K, Kim HY, Chiba T et al (2011) Geological evidence of recurrent great Kanto earthquakes at the Miura Peninsula, Japan. J Geophys Res Solid Earth 116:B12408 https://doi.org/10.1029/2011JB008639

Shishikura M, Echigo T, Maemoku H et al (2008) Height and ages of uplifted sessile assemblage distributed along the southern coast of the Kii Peninsula, southcentral Japan - reconstruction ofmulti-segment earthquake history along the Nankai Trough. Ann Rep Active Fault and Paleoearthquake Res 8:267-280 (In Japanese)

Shishikura M, Sawai Y, Namegaya Y (2010) Reproduction of mega-tsunami that occurred in Heian period AD 869 Jogan tsunami. AFREC News 16:1-10 (in Japanese)

Sloss CR, Murray-Wallace CV, Jones BG (2007) Holocene sea-level change on the southeast coast of Australia: a review. The Holocene 17:999-1014. https://doi. org/10.1177/0959683607082415

Takata H, Irizuki T, Ishida K, 2006. Living benthic foraminifera from Urauchi Bay, Kamikoshiki-jima Island, Kagoshima Prefecture, southern Japan. LAGUNA 13: 99-107 (in Japanese with English abstract).

Takata H, Khim B-K, Cheong D et al (2016) Holocene benthic foraminiferal faunas in coastal deposits of the Nakgdong River delta (Korea) and Izumo Plain (Japan). Quat Int 392:13-24

Tanabe S, Hori K, Momohara A, Nakashima R (2016) Verification of the "Yayoi regression" in the Tonegawa Lowland, central Japan. J Geol Soc Japan 122: 135-153 in Japanese with English abstract

Tsuchi R (1955) The palaeo-ecological analysis of the molluscan remains dredged from Orido Bay in Shimizu Harbor, the Pacific coast of Japan. Rep Lib Ar Fac Shizuoka Univ (Nat Sci) 10:15-24

Woodroffe CD, McGregor HV, Lambeck K, Smithers SG, Fink D (2012) MidPacific microatolls record sea-level stability over the past $5000 \mathrm{yr}$. Geology 40(10):951-954

\section{Publisher's Note}

Springer Nature remains neutral with regard to jurisdictional claims in published maps and institutional affiliations.

\section{Submit your manuscript to a SpringerOpen ${ }^{\circ}$ journal and benefit from:}

- Convenient online submission

Rigorous peer review

- Open access: articles freely available online

High visibility within the field

- Retaining the copyright to your article

Submit your next manuscript at $\boldsymbol{\nabla}$ springeropen.com 